\title{
Aspects of Image Regwastration in Digital Image Processing
}

\author{
Jeffrin Rajan M, Sugumar.v, Aravindasamy R, P.Kavitha
}

\begin{abstract}
The procedure of image enlwastmentwas to adjusting two or more pictures of the same scene. Thwas procedure worried with assigning one picture as the reference also applying geometric change to alternate pictures so they adjust to suggestion. Ordinarily, the pictures are caught under variable conditions that can change camera setting. Mwasalignment can likewwase be the consequence of lens also sensor twwasts or differentiate between catch gadgets. A geometric change maps areas in one picture to late areas in another. The progression of conclusive the ideal geometric change parameters key to the picture enlwastment process. Picture enlwastmentwas intermittently appropriate as a preparatory stride as a part of other picture halsoling applications. For instance, you can utilize picture enlwastment to adjust satellite pictures or to grouping of restorative pictures caught with diverse symptomatic modalities like MRI also SPECT. Picture enrollment permits you to examination of diverse picture estimations.
\end{abstract}

Keywords: wavelets, compression, modality, degradation

\section{INTRODUCTION}

The picture adapting strategies to clarifies with control of advanced pictures through a computerized PC. It was a sublet frameworks absolutely of pictures. Plunge concentration of adding a PC framework that perform shalsoling on a picture. The information of a picture of framework halsoles the picture halsole proficient calculations, to produce picture. Picture adapting fundamentally incorporates the accompanying three stages: (an) Importing the picture by means of picture obtaining instruments (b) Analyze also controlling the picture also (c) Output in which result can be modified picture or report that depends on picture examination. There are two sorts of strategies appropriate for picture adapting to be specific, simple also computerized picture halsoling[1],[ 3],[5].Simple picture adapting that appropriate of that printed copies like that picture printouts also image duplicates. Image experts that different essentials understalsoing while appropriate that usual system. Computerized image adapting strategies helped that control of that advanced images by appropriate PCs. The three general stages appropriate computerized method of

Revised Manuscript Received on July 22, 2019.

Jeffrin Rajan M, Student, Department of CSE, Bharath Institute of Higher Education and Research, Tambaram, India

Sugumar V, Student, Department of IT, Bharath Institute of Higher Education and Research, Tambaram, India

Aravindasamy R, Student, Department of CSE, Bharath Institute of Higher Education and Research, Tambaram, India

P. Kavitha, Department of IT, Bharath Institute of Higher Education and Research, Tambaram, India pre-adapting, improvement, also show, data extraction[2],[4],[6]

\section{MATERIALS AND METHODOLOGY}

a) Picture Procurement: Picture obtaining that picture handling that comprehensively describe as recovering that picture from source, as ruleequipment based source, which can be gone through that procedures want to develop a short time delay. Affecting picture securing was the initial phase in the work process succession in light of the fact these, without aimagehandling was un-realistic. That picture that was gained was totally grungy also was the consequence that equipment was appropriate to produce it, which can be essential that few fields a reliable benchmark from that work. One of the great objectives was procedure that has a wellspring of information these works inside such controlled also measured rules of a same picture[7],[ 9], [11] (b) Image preprocessing: Image pre-adapting can to a great degree build the exactness of that optical review. Some channel operations that guaranteed image points of interest empower that simpler are speedier assessment. Clients can upgrade a camera picture with only a couple clicks.

(c) Image Upgrade: The unmistakable goal of picture improvement was to prepare a given image that the outcome was more suitable the first picture of a separate application. Theimage highlights like edges, limits, and to make a realistic show most supportive for presentation also investigation.

(d) Image Rebuilding: That motivation picture reclamation was to "make up for" "fix" imperfections that debase a picture. Decrease comes that numerous structures, the example, sequence obscure also commotion. The movement obscure, it was conceivable to concoct gauge of the real obscuring work also"fix" the obscure to restore that first picture. The situations of aimagewas ruined by commotion, that best we might want to do was to reward for the debasement it brought on. It was venture, we present also execute a few of the strategies appropriate a part of the picture adapting world to restore picture [8],[ 10],[12]

(e) Color picture handling: The human framework can dissect a huge number of shading shades also intensities; it was around 100 shades of image darkness. It was manner, in that picture, of more data contained in that shading, also it was additional data can be appropriate to improve image investigation, e.g. image proof also extraction taking into account shading. There are outright amounts are appropriate to depict a particular shading. The tone was supreme on that predominant wavelength[13], [15], [ 17].

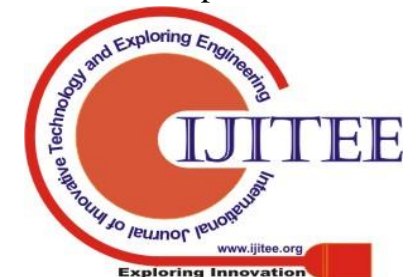




\section{Aspects of Image Regwastration in Digital Image Processing}

(f) Wavelets also Multi-determination Processing: Wavelets are the establishment for characterizing pictures in different degrees of determination. Pictures subdivision progressively into littler areas for information pressure also for pyramidal representation [14],[16], [18]

(g) Compression: Compression manages strategies for the stockpiling required to store a picture or the data transfer capacity to transmit it. Particularly in the employments of web it was all that much important to pack information.

(h)Morphological Processing: Its instruments for infer picture parts that was helpful in the representation also depiction of shape.

(i) Segmentation: Segmentation techniques parcel a picture into its constituent parts or protests. As a rule, self-sufficient division was amongst the most troublesome error in advanced picture handling. A tough division was the procedure far toward effective arrangement of imaging items to be recognized independently[19],[21],[23].

(j) Representation also Description: extricating also portrayal quite often take after the yield of a division stage, which for the most part was crude pixel information, constituting either the limit of a locale or every one of the focuses in the area itself. Picking a characterizing was just piece of the answer for changing crude information into a structure suitable for resulting PC adapting. Removing characteristics that some of quantitative data that interest are essential for separating individual class items from another class[20], [22], [24]

(k) Object acknowledgment: Recognition implies that appoints a mark, for example, "vehicle" to an item in view of its descriptors.

(1) Knowledge Base: Knowledge may be as basic as enumerating areas of a picture where the data of interest was known not found, in that was way constraining the pursuit that must be directed in looking for that data. The learning base additionally can be very perplexing, for example, a necessary rundown of all significant conceivable imperfections in a materials examination a picture database containing high-determination satellite pictures of an area regarding change-elevation applications[32],[34],[36]

\section{RESULTS AND DISCUSSIONS}

I. Highlight acknowledgment: In that frameworks, striking also articles like corners, close utmost territories, edges, shapes, line crossing point are essentially or in a perfect world unequivocally. These components are used to further taking care of. Those segments point delegates that centre of gravity in that specific centerit's also called control centers. To find highlight sets of informationalso picture have enough essential parts.

II. Highlight planning: In thatcase, correspondence segments recognized that identified picture also perceived in that referenced picture was set up. The particular segment descriptors also comparability measures close by spatial associations among the components are used hence. The segment change routines should adequately to be to that perceived components[37],[39],[41].

III. Change estimation: In this sortalso parameters of the claimed mapping limits, sequencing the picture alsoimpute picture are assessed. The parameters of mapping enrolled limited by technique for the highlight. This kind of mapping framework picked by a data about the getting handlealso expected picture defilement. If no previous information was available then the model should versatile also typical degradation was appear.

IV. Picture reconsidering also change: This photo was changed the strategy for that mapping limits. Picture data in non entire number headings were enrolled the fitting presentation model. The choice of taking after procedure depends on that trade of between the asked for precision of the multifaceted nature[38],[40]

\section{CONCLUSION}

The purpose of a photo selection was to find looking at down to earth zones in two or more pictures. It was used as a piece of various fields like PC vision, therapeutic imaging, also remote recognizing. It was required for joining information taken from sensors choosing changes in pictures taken at assorted time (multi common selection), gathering three dimensional information from pictures where camera or the things in the scene was moving (multi view selection) or scene to model enlistment.

\section{REFERENCES}

[1] Kumarave A., Rangarajan K.,Algorithm for automaton specification for exploring dynamic labyrinths,Indian Journal of Science and Technology,V-6,I-SUPPL5,PP-4554-4559,Y-2013

[2] P. Kavitha, S. Prabakaran "A Novel Hybrid Segmentation Method with Particle Swarm Optimization and Fuzzy C-Mean Based On Partitioning the Image for Detecting Lung Cancer" International Journal of Engineering and Advanced Technology (IJEAT) ISSN: 2249-8958, Volume-8 Issue-5, June 2019

[3] Kumaravel A., Meetei O.N.,An application of non-uniform cellular automata for efficient cryptography,2013 IEEE Conference on Information and Communication Technologies, ICT 2013,V-,I-,PP-1200-1205,Y-2013

[4] Kumarave A., Rangarajan K.,Routing alogrithm over semi-regular tessellations,2013 IEEE Conference on Information and Communication Technologies, ICT 2013,V-,I-,PP-1180-1184,Y-2013

[5] P. Kavitha, S. Prabakaran "Designing a Feature Vector for Statistical Texture Analysis of Brain Tumor" International Journal of Engineering and Advanced Technology (IJEAT) ISSN: 2249-8958, Volume-8 Issue-5, June 2019

[6] Dutta P., Kumaravel A.,A novel approach to trust based identification of leaders in social networks,Indian Journal of Science and Technology,V-9,I-10,PP--,Y-2016

[7] Kumaravel A., Dutta P.,Application of Pca for context selection for collaborative filtering,Middle - East Journal of Scientific Research,V-20,I-1,PP-88-93,Y-2014

[8] Kumaravel A., Rangarajan K.,Constructing an automaton for exploring dynamic labyrinths, 2012 International Conference on Radar, Communication and Computing, ICRCC 2012,V-,I-,PP-161-165,Y-2012

[9] P. Kavitha, S. Prabakaran "Adaptive Bilateral Filter for Multi-Resolution in Brain Tumor Recognition" International Journal of Innovative Technology and Exploring Engineering (IJITEE) ISSN: 2278-3075, Volume-8 Issue-8 June, 2019

[10] Kumaravel A.,Comparison of two multi-classification approaches for detecting network attacks,World Applied Sciences Journal,V-27,I-11,PP-1461-1465,Y-2013

[11]Tariq J., Kumaravel A.,Construction of cellular automata over hexagonal and triangular tessellations for path planning of multi-robots,2016 IEEE International Conference on Computational Intelligence and Computing Research, ICCIC 2016,V-,I-,PP--,Y-2017

[12] Sudha M., Kumaravel A.,Analysis and measurement of wave guides using poisson method,Indonesian Journal of Electrical Engineering and Computer

\section{Published By:}


Science,V-8,I-2,PP-546-548,Y-2017

[13] Ayyappan G., Nalini C., Kumaravel A.,Various approaches of knowledge transfer in academic social network,International Journal of Engineering and Technology,V-,I-,PP-2791-2794,Y-2017

[14] Kaliyamurthie, K.P., Sivaraman, K., Ramesh, S. Imposing patient data privacy in wireless medical sensor networks through homomorphic cryptosystems 2016, Journal of Chemical and Pharmaceutical Sciences92.

[15] Kaliyamurthie, K.P., Balasubramanian, P.C. An approach to multi secure to historical malformed documents using integer ripple transfiguration2016 Journal of Chemical and Pharmaceutical Sciences92.

[16]A.Sangeetha,C.Nalini,"Semantic Ranking based on keywords extractions in the web", International Journal of Engineering \& Technology, 7 (2.6) (2018) 290-292

[17]S.V.GayathiriDevi,C.Nalini,N.Kumar,"An efficient software verification using multi-layered software verification tool "International Journal of Engineering \& Technology, 7(2.21)2018 454-457

[18]C.Nalini,ShwtambariKharabe,"A Comparative Study On Different Techniques Used For Finger - Vein Authentication", International Journal Of Pure And Applied Mathematics, Volume 116 No. 8 2017, 327-333, Issn: 1314-3395

[19]M.S. Vivekanandan and Dr. C. Rajabhushanam, "Enabling Privacy Protection and Content Assurance in Geo-Social Networks", International Journal of Innovative Research in Management, Engineering and Technology, Vol 3, Issue 4, pp. 49-55, April 2018.

[20]Dr. C. Rajabhushanam, V. Karthik, and G. Vivek, "Elasticity in Cloud Computing", International Journal of Innovative Research in Management, Engineering and Technology, Vol 3, Issue 4, pp. 104-111, April 2018.

[21]K. Rangaswamy and Dr. C. Rajabhushanamc, "CCN-Based Congestion Control Mechanism In Dynamic Networks", International Journal of Innovative Research in Management, Engineering and Technology, Vol 3, Issue 4, pp. 117-119, April 2018

[22] Kavitha, R., Nedunchelian, R., "Domain-specific Search engine optimization using healthcare ontology and a neural network backpropagation approach", 2017, Research Journal of Biotechnology, Special Issue 2:157-166

[23] Kavitha, G., Kavitha, R., "An analysis to improve throughput of high-power hubs in mobile ad hoc network" , 2016, Journal of Chemical and Pharmaceutical Sciences, Vol-9, Issue-2: 361-363

[24] Kavitha, G., Kavitha, R., "Dipping interference to supplement throughput in MANET" , 2016, Journal of Chemical and Pharmaceutical Sciences, Vol-9, Issue-2: 357-360

[25]Michael, G., Chandrasekar, A.,'Leader election based malicious detection and response system in MANET using mechanism design approach", Journal of Chemical and Pharmaceutical Sciences(JCPS) Volume 9 Issue 2, April - June 2016

[26] Michael, G., Chandrasekar, A.,"Modeling of detection of camouflaging worm using epidemic dynamic model and power spectral density", Journal of Chemical and Pharmaceutical Sciences(JCPS) Volume 9 Issue 2, April June 2016 .

[27]Pothumani, S., Sriram, M., Sridhar, J., Arul Selvan, G., Secure mobile agents communication on intranet,Journal of Chemical and Pharmaceutical Sciences, volume 9, Issue 3, Pg No S32-S35, 2016

[28]Pothumani, S., Sriram, M., Sridhar, Various schemes for database encryption-a survey, Journal of Chemical and Pharmaceutical Sciences, volume 9, Issue 3, Pg NoS103-S106, 2016

[29]Pothumani, S., Sriram, M., Sridhar, A novel economic framework for cloud and grid computing, Journal of Chemical and Pharmaceutical Sciences, volume 9, Issue 3, Pg No S29-S31, 2016

[30] Priya, N., Sridhar, J., Sriram, M. "Ecommerce Transaction Security Challenges and Prevention Methods- New Approach” 2016 ,Journal of Chemical and Pharmaceutical Sciences, JCPS Volume 9 Issue 3.page no:S66-S68 .

[31] Priya, N.,Sridhar,J.,Sriram, M.“Vehicular cloud computing security issues and solutions" Journal of Chemical and Pharmaceutical Sciences(JCPS) Volume 9 Issue 2, April - June 2016

[32] Priya, N., Sridhar, J., Sriram, M. "Mobile large data storage security in cloud computing environment-a new approach" JCPS Volume 9 Issue 2. April - June 2016

[33] Anuradha.C, Khanna.V, "Improving network performance and security in WSN using decentralized hypothesis testing "Journal of Chemical and Pharmaceutical Sciences(JCPS) Volume 9 Issue 2, April - June 2016

[34] Anuradha.C, Khanna.V, "A novel gsm based control for e-devices“ Journal of Chemical and Pharmaceutical Sciences(JCPS) Volume 9 Issue 2, April June 2016 .

[35] Anuradha.C, Khanna.V, "Secured privacy preserving sharing and data integration in mobile web environments " Journal of Chemical and Pharmaceutical Sciences(JCPS) Volume 9 Issue 2, April - June 2016
[36] Sundarraj, B., Kaliyamurthie, K.P. Social network analysis for decisive the ultimate classification from the ensemble to boost accuracy rates 2016 International Journal of Pharmacy and Technology 8

[37] Sundarraj, B., Kaliyamurthie, K.P. A content-based spam filtering approach victimisation artificial neural networks 2016 International Journal of Pharmacy and Technology83.

[38] Sundarraj, B., Kaliyamurthie, K.P. Remote sensing imaging for satellite image segmentation 2016 International Journal of Pharmacy and Technology8 3.

[39] Sivaraman, K., Senthil, M. Intuitive driver proxy control using artificial intelligence 2016 International Journal of Pharmacy and Technology84

[40] Sivaraman, K., Kaliyamurthie, K.P. Cloud computing in mobile technology 2016 Journal of Chemical and Pharmaceutical Sciences92.

[41] Sivaraman, K., Khanna, V. Implementation of an extension for browser to detect vulnerable elements on web pages and avoid click jacking 2016 Journal of Chemical and Pharmaceutical Sciences92.

\section{AUTHORS PROFILE}

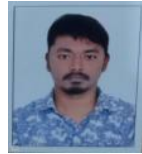

Jeffrin Rajan M, Student, Department of Computer Science \& Engineering, Bharath Institute of Higher Education and Research, Chennai, India

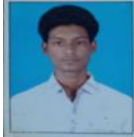

Sugumar V, Student, Department of IT, Bharath Institute of Higher Education and Research, Tambaram, India

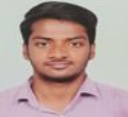

Aravindasamy R, Student, Department of Computer Science \& Engineering, Bharath Institute of Higher Education and Research, Chennai, India

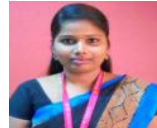

P. Kavitha, Department of IT, Bharath Institute of Higher Education and Research, Tambaram, India 